Zeszyty Naukowe Szkoły Głównej Gospodarstwa Wiejskiego w Warszawie

Problemy Rolnictwa Światowego tom 18 (XXXIII), zeszyt 4, 2018: 60-68

DOI: $10.22630 /$ PRS.2018.18.4.97

Piotr Szajner $^{1}$

Instytut Ekonomiki Rolnictwa i Gospodarki Żywnościowej - Państwowy Instytut

Badawczy w Warszawie

\title{
Ewolucja światowego rynku piwa
}

\section{The Evolution of World Beer Market}

\begin{abstract}
Synopsis. W latach 1980-2016 światowy rynek piwa charakteryzował się wysoką dynamiką rozwoju. Produkcja i obroty handlu zagranicznego znacząco wzrosły. Istotny wpływ miały na to procesy globalizacyjne. Światowa produkcja piwa jest zdominowana przez duże koncerny browarnicze, ale w ostatnich latach ich udział w rynku zmniejszył w związku z rozwojem produkcji w małych browarach. Rosnąca produkcja piwa generuje duży popyt na surowce wytwarzane w działach pierwotnego przetwórstwa żywności (słód, ekstrakt chmielowy, cukier). Na polskim rynku piwa były obserwowane analogiczne tendencje. Duże bezpośrednie inwestycje zagraniczne, koncentracja struktur podmiotowych i w konsekwencji dynamiczny wzrost produkcji i eksportu. Na krajowym rynku także wzrasta produkcji w małych browarach.
\end{abstract}

Słowa kluczowe: rynek, piwo, chmiel, globalizacja

\begin{abstract}
Over the period of 1980-2016 the world beer market showed a dynamic development. Both the production and foreign trade volumes considerably increased, which largely resulted from globalisation processes. The production of beer in the world is dominated with large brewing companies. However in recent years their share contracted due to expansion of small-scale brewing. Growing production of beer generates demand for raw materials (malt, hops extract, sugar). The world tendencies were mirrored on the Polish market. Large foreign direct investments along with concentration of production triggered a dynamic growth of production and exports. The share of small breweries in Poland has recently been growing as well.
\end{abstract}

Key words: market, beer, hop, globalisation

JEL Classification: D43

\section{Wprowadzenie}

Piwo jest napojem alkoholowym, który wytwarzano już w starożytności. Udokumentowane przekazy historyczne potwierdzają produkcję w starożytnym Babilonie i Egipcie. Należy również podkreślić, że rynek piwa od samego początku należał do najbardziej uregulowanych rynków, a podstawę regulacji stanowiły system podatkowy i koncesyjny (Wiśniewski 1993). W Europie dynamiczny rozwój rzemiosła piwowarskiego rozpoczął się w średniowieczu. W ujęciu regionalnym dotyczył on przede wszystkim krajów, w których ze względów klimatycznych nie mogła rozwinąć się uprawa winorośli. Odkrycia naukowe w XVIII i XIX w. (np. A, Lavoisier, L. Pasteur, itp.) spowodowały, że rzemieślnicze browary przekształcały się w nowoczesne zakłady o charakterze przemysłowym. Duży postęp

\footnotetext{
${ }^{1}$ dr inż., ul. Świętokrzyska 20, 00-002 Warszawa, e-mail: szajner@ierigz.waw.pl; https://orcid.org/0000-0002-4786-1962
} 
odnotowano także w organizacji i zarządzaniu przedsiębiorstwami piwowarskimi, które stały się fundamentem wielu transnarodowych koncernów. Modernizacja produkcji i poprawa efektywności gospodarowania przyczyniły się do ogromnego poszerzenia oferty asortymentowej (Bierkompendium 2018). W ostatnich latach światowy rynek piwa dynamicznie rozwijał się, a sprzyjały temu przybierające na sile procesy globalizacyjne. Niezależnie od dużych bezpośrednich inwestycji zagranicznych transnarodowych koncernów piwowarskich $\mathrm{w}$ wielu krajach utrzymała się utrwalona przez wieki tradycja produkcji $\mathrm{w}$ lokalnych browarach. Rozwój rynku piwa był silnie zintegrowany rozwojem kultury i sportu, gdyż koncerty i wydarzenia sportowe były sponsorowane przez koncerny piwowarskie. Celem artykułu jest ocena ewolucji światowego rynku piwa i porównanie jej $\mathrm{z}$ tendencjami obserwowanymi na rynku krajowym.

\section{Dane i metody}

W ocenie tendencji na światowym rynku piwa wykorzystano analizę dynamiki produkcji i handlu zagranicznego. Analizę średniorocznej dynamiki przeprowadzono dwoma metodami w celu potwierdzania poprawności uzyskanych wyników. Pierwsza metoda bazowała na koncepcji procentu składanego poprzez przekształcenie formuły na stopę zwrotu (1) (Luderer, Nollau, Vetters 2010). Drugim podejściem analitycznym było wykorzystanie wykładniczej funkcji trendu. W formule funkcji wykładniczej współczynnik przy wykładniku potęgi odpowiada średniorocznej dynamice zmian (2) (Aczel 2000), (Górecki 2013). Metody badawcze obejmowały także zmiany struktury podmiotowej rynku oraz struktury geograficznej produkcji i handlu zagranicznego.

$$
P_{n}=P_{0}\left(1+\frac{r}{100}\right)^{n-1}=>r=\left(\sqrt[n-1]{\frac{P_{n}}{P_{0}}}-1\right) 100
$$

gdzie:

$P_{0}$ - produkcja w okresie początkowym,

$P_{n}-$ produkcja w okresie końcowym,

$r$ - średnioroczna dynamika produkcji.

gdzie:

$$
P(n)=\mathrm{a} e^{b n}
$$

$P$ - zmienna zależna (produkcja),

$n$-zmienna niezależna (czas),

$a, b$ - współczynniki funkcji wykładniczej.

Dane statystyczne dotyczące światowej produkcji piwa i chmielu pochodzily $\mathrm{z}$ raportów firmy analitycznej Barth-Haas Group ${ }^{2}$. Dane statystyczne w zakresie światowego handlu zagranicznego pochodziły z FAO i UN Comtrade. Zakres czasowy analizy rynku światowego obejmował lata 1980-2016. Dane dotyczace krajowej produkcji (1990 -2016) i struktury podmiotowej rynku (1999-2015) pochodziły z GUS. W ocenie polskiego handlu zagranicznego wykorzystywano dane Centrum Informatyki Handlu Zagranicznego (19952003) i Centrum Analitycznego Administracji Celnej Ministerstwa Finansów (2004-2016).

\footnotetext{
${ }^{2}$ Barth-Haas Group: Barth Market Reports www.barthhaasgroup.com/en/media-library/
} 


\section{Światowa produkcja piwa}

W latach 1980-2016 światowa produkcja piwa wykazywała tendencję wzrostową. W omawianym okresie produkcja wzrosła dwukrotnie do $1958 \mathrm{mln}$ hl. Analiza statystyczna wykazała, że średnioroczna dynamika produkcji wyniosła ok. $2 \%$. Duże różnice dynamiki produkcji wystapiły w układzie regionalnym. Wzrost produkcji odnotowano na wszystkich kontynentach z wyjątkiem Oceanii. Decydujący wpływ na wzrost światowej produkcji miała dynamicznie rosnąca produkcja na kontynencie azjatyckim. Średnioroczna dynamika produkcji w Azji wynosiła ok. 6\% W rezultacie produkcja w Azji zwiększyła się prawie dziewięciokrotnie i w 2016 r. osiagnęła poziom ok. $681 \mathrm{mln}$ hl. W Ameryce Płd., Ameryce Płn. i Europie, które charakteryzują się ugruntowanymi tradycjami piwowarskimi, dynamika produkcji była znacznie mniejsza. Na kontynentach amerykańskich produkcja zwiększała się średniorocznie o 1,5\% do ok. $581 \mathrm{mln} \mathrm{hl}$. W Europie średnioroczna dynamika produkcji była niewielka $(0,8 \%)$ i w 2016 r. wyniosła ona ok. $531 \mathrm{mln}$ hl. Niewielka dynamika produkcji w Amerykach i Europie wynika z faktu, że popyt jest bliski granicy nasycenia i możliwości jego wzrostu są ograniczone. Relatywnie wysoką dynamiką (1,5\% rocznie) charakteryzowała się produkcja piwa w Afryce, która w analizowanym okresie zwiększyła się prawie czterokrotnie do $145 \mathrm{mln}$ hl (tab. 1, rys. 1). Na kontynentach azjatyckim i afrykańskim stymulatorem wzrostu produkcji był duży wzrost popytu w wyniku poprawy sytuacji dochodowej ludności oraz zmiany modelu konsumpcji żywności, w tym także używek (Pingali 2006). Drugim czynnikiem determinującym wzrost produkcji były procesy globalizacyjne, których wyrazem były duże bezpośrednie inwestycje transnarodowych koncernów globalnych w krajach przechodzących transformację gospodarczą. Analogiczne tendencje odnotowano w krajach Europy Środkowo-Wschodniej.

Tabela 1. Dynamika światowej produkcji piwa w latach 1980-2016

Table 1. Dynamics of the world beer production in 1980-2016

\begin{tabular}{|c|c|c|c|c|}
\hline \multirow[b]{2}{*}{ Wyszczególnienie } & \multirow[b]{2}{*}{2016} & \multirow[b]{2}{*}{$1980=100$} & \multicolumn{2}{|c|}{ Średnioroczna dynamika } \\
\hline & & & $\begin{array}{c}\text { formula procentu } \\
\text { skladnego }\end{array}$ & $\begin{array}{c}\text { wykladnicza } \\
\text { funkcja trendu }\end{array}$ \\
\hline Afryka & 145,0 & 369,0 & 3,7 & 3,2 \\
\hline Ameryka Płd i Ameryka Płn. & 580,7 & 165,0 & 1,4 & 1,5 \\
\hline Azja & 680,6 & 860,4 & 6,2 & 6,4 \\
\hline Europa & 530,8 & 121,4 & 0,5 & 0,8 \\
\hline Oceania & 20,3 & 84,6 & $-0,5$ & $-0,5$ \\
\hline Świat & 1957,5 & 210,2 & 2,1 & 2,3 \\
\hline
\end{tabular}

Źródło: obliczenia własne, dane Barht-Haas Group.

Zróżnicowana dynamika produkcji na poszczególnych kontynentach skutkowała zmianami struktury geograficznej światowej produkcji. W 1980 r. największy udział w produkcji miały Europa (ok. 47\%) oraz Ameryka Płd. i Ameryka Płn. (łącznie ok. 38\%). Dynamicznie rosnąca produkcja na kontynentach azjatyckim i afrykańskim spowodowała, że Europa i Ameryki systematycznie zmniejszały udział w światowym rynku. W 2016 r. największy udział w światowej produkcji miała Azja (ok. 35\%), a udział Afryki zwiększył się do ok. 7\%. Udział Ameryk i Europy zmniejszył się odpowiednio do 30\% i 27\% (tab. 2).

Światowa produkcja piwa jest silnie skoncentrowana w układzie krajów, gdyż piętnaście krajów wytwarza ok. $75 \%$ światowej produkcji. W analizowanym okresie 
największą średnioroczną dynamiką produkcji charakteryzowały się Chiny (12,8\%), które w $2016 \mathrm{r}$. były największym producentem $(460 \mathrm{mln} \mathrm{hl})$. W Brazylii i Meksyku produkcja zwiększała się o ok. 4\% rocznie i w $2016 \mathrm{r}$. osiagnęła odpowiednio $139 \mathrm{mln}$ hl i $97 \mathrm{mln}$ hl. Na kontynencie azjatyckim duży wzrost produkcji odnotowano także w Wietnamie (40 mln hl). W grupie największych światowych producentów wysoką dynamikę produkcji odnotowano także w Polsce, gdzie produkcja zwiększała się średniorocznie o 3,7\% do 41,4 $\mathrm{mln}$ hl. Analogiczna dynamika produkcji wystapiła w RPA, gdzie wytworzono ok. $32 \mathrm{mln}$ hl. Dużymi producentami są także Rosja (ok. $78 \mathrm{mln}$ hl) i Japonia $(55 \mathrm{mln} \mathrm{hl})$, ale dynamika produkcji była niewielka (po ok. $0,5 \%$ rocznie).

Odmienne tendencje obserwowano $w$ krajach rozwiniętych gospodarczo i charakteryzujących się nowoczesnym przemysłem piwowarskim. W Niemczech ${ }^{3} \mathrm{w}$ latach 1980-2016 produkcja piwa spadała o średniorocznie o 0,6\% do ok. $95 \mathrm{mln}$ hl. W Wielkiej Brytanii średnioroczne tempo spadku produkcji było jeszcze większe $(1,1 \%)$, która zmniejszyła się do $44 \mathrm{mln}$ hl. W USA średnioroczna dynamika produkcji była niewielka $(0,1 \%)$ i w konsekwencji spadła ona do ok. $221 \mathrm{mln} \mathrm{hl}$.


Rys. 1. Światowa produkcja piwa

Fig. 1. The world production of beer

Źródło: obliczenie własne, dane Barth-Haas Group.

Tabela 2. Geograficzna struktura światowej produkcji piwa

Table 2. Geographical structure of beer production

\begin{tabular}{lrrrrr}
\hline \multicolumn{1}{c}{ Wyszczególnienie } & $\mathbf{1 9 8 0}$ & $\mathbf{1 9 9 0}$ & $\mathbf{2 0 0 0}$ & $\mathbf{2 0 1 0}$ & $\mathbf{2 0 1 6}$ \\
\hline Afryka & 4,2 & 5,1 & 4,4 & 5,6 & 7,4 \\
Ameryka Płd i Ameryka Płn. & 37,8 & 36,7 & 34,0 & 29,9 & 29,7 \\
Azja & 8,5 & 16,3 & 25,8 & 33,9 & 34,8 \\
Europa & 46,9 & 39,8 & 34,3 & 29,4 & 27,1 \\
Oceania & 2,6 & 2,1 & 1,5 & 1,2 & 1,0 \\
Świat & $\mathbf{1 0 0 , 0}$ & $\mathbf{1 0 0 , 0}$ & $\mathbf{1 0 0 , 0}$ & $\mathbf{1 0 0 , 0}$ & $\mathbf{1 0 0 , 0}$ \\
\hline
\end{tabular}

Źródło: obliczenia własne, dane Barth-Haas Group.

\footnotetext{
3 W latach 1980-1989 produkcję w Niemczech potraktowano jako sumę produkcji w Niemieckiej Republice Demokratycznej i w Republice Federalnej Niemiec.
} 


\section{Procesy globalizacyjne na światowym rynku piwa}

Zmiany zachodzące w światowej produkcji i przetwórstwie żywności mają podobny charakter, jak w innych sektorach gospodarki, a ich motorem były postęp technologiczny oraz postępująca liberalizacja przepływów kapitałowych, wspierająca bezpośrednie inwestycje zagraniczne (Szymański 2002). W rezultacie na światowym rynku żywności coraz większą rolę odgrywają duże korporacje transnarodowe, które rozszerzają swoją działalność na obszar innych krajów i kontynentów. Globalizacja znacząco zmieniła podejście do problematyki geograficznego zakresu rynku (Pietrzak 2014).

Branża piwowarska należy do działów przemysłu spożywczego, które wykazują zaawansowane procesy globalizacyjne. Światowa produkcja piwa jest zdominowana przez transnarodowe koncerny browarnicze. Duże bezpośrednie inwestycje zagraniczne tych koncernów mają przede wszystkim na celu ekspansję rynkową i wysokie stopy zwrotu z zainwestowanego kapitału (Łyszkiewicz 2000), (Köster 2010). W konsekwencji światowy rynek piwa charakteryzuje się bardzo silną walką konkurencyjną (Porter 2006). W ostatnich latach w wielu krajach dynamicznie rośnie jednak produkcja w małych lokalnych browarach, które zwiększają swój udział w rynku. W 2013 r. czterdzieści największych koncernów browarniczych wytworzyło 81,4\% światowej produkcji piwa, a dziesięć największych koncernów 64,6\%. W 2016 r. największe koncerny browarnicze zmniejszyły swój udział w światowej produkcji odpowiednio do 78,7\% i 62,5\% (tab. 3).

Tabela 3. Produkcja transnarodowych koncernów browarniczych

Table 3. The output of trans-national brewing companies

\begin{tabular}{lrrlrr}
\hline \multicolumn{1}{c}{$\mathbf{2 0 1 3}$} & & \multicolumn{2}{c}{$\mathbf{2 0 1 6}$} \\
\multicolumn{1}{c}{ Wyszczególnienie } & mln hl & \multicolumn{1}{c}{ \% } & \multicolumn{1}{c}{ Wyszczególnienie } & mln hl & \% \\
\hline Ab InBev (Belgia) & 399,0 & 20,2 & Ab InBev (Belgia) & 433,9 & 22,2 \\
SABMiller (W. Brytania) & 187,4 & 9,5 & Heineken (Holandia) & 200,1 & 10,2 \\
Heineken (Holandia) & 178,3 & 9,0 & Res. SnowBreweries (Chiny) & 118,8 & 6,1 \\
Carlsberg (Dania) & 119,7 & 6,1 & Carlsberg (Dania) & 116,9 & 6,0 \\
Res.SnowBreweries (Chiny) & 117,1 & 5,9 & Molson-Cross (USA) & 95,2 & 4,9 \\
Tsingato Brewery (Chiny) & 78,3 & 4,0 & Tsingato Brewery (Chiny) & 79,2 & 4,0 \\
Molson-Cross (USA) & 59,7 & 3,0 & Asahi (Japonia) & 59,0 & 3,0 \\
Yanjing (Chiny) & 57,1 & 2,9 & Yanjing (Chiny) & 45,0 & 2,3 \\
Kirin (Japonia) & 49,3 & 2,5 & Kirin (Japonia) & 42,5 & 2,2 \\
BGI (Francja) & 28,4 & 1,4 & BGI (Francja) & 32,9 & 1,7 \\
Razem 10 koncernów & $\mathbf{1 2 7 4 , 3}$ & $\mathbf{6 4 , 6}$ & Razem 10 koncernów & $\mathbf{1 2 2 3 , 5}$ & $\mathbf{6 2 , 5}$ \\
Razem 40 koncernów & $\mathbf{1 ~ 6 0 6 , 1}$ & $\mathbf{8 1 , 4}$ & Razem 40 koncernów & $\mathbf{1 ~ 5 4 0 , 7}$ & $\mathbf{7 8 , 7}$ \\
\hline
\end{tabular}

Źródło: obliczenia własne, dane Barth-Haas Group.

$\mathrm{Na}$ polskim rynku piwa obserwowano analogiczne tendencje, jak w na rynku światowym (Urban 2004). Krajowy przemysł piwowarski należy do działów przemysłu spożywczego, które charakteryzowały się dużymi bezpośrednimi inwestycjami zagranicznymi. W latach 1990-2004 łączna wartość tych inwestycji wyniosła 1,2 mld USD (Chechelski 2008). Większe inwestycje zagraniczne odnotowano jedynie w przemyśle tytoniowym. Po akcesji do UE w branży piwowarskiej nie było znaczących bezpośrednich 
inwestycji zagranicznych. W wyniku procesów prywatyzacyjnych, a następnie przemian strukturalnych polski przemysł piwowarski charakteryzuje się bardzo skoncentrowaną strukturą podmiotową (Drożdż 2016). Kluczową rolę odgrywają trzy transnarodowe koncerny browarnicze, które wytwarzają łącznie ok. 80\% produkcji (PKO BP 2017). W ostatnich latach coraz większy udział w produkcji mają małe lokalne browary. Według danych GUS w 1999 r. duże przedsiębiorstwa (>250 zatrudnionych) generowały 93\% przychodów ze sprzedaży. W 2015 r. udział tych przedsiębiorstw w przychodach branży zmniejszył się do $83 \%$. W tym samym czasie małe firmy (10-49 zatrudnionych) zwiększyły swój udział w przychodach ze sprzedaży przemysłu browarniczych z dwóch do 7\% (rys. 2).
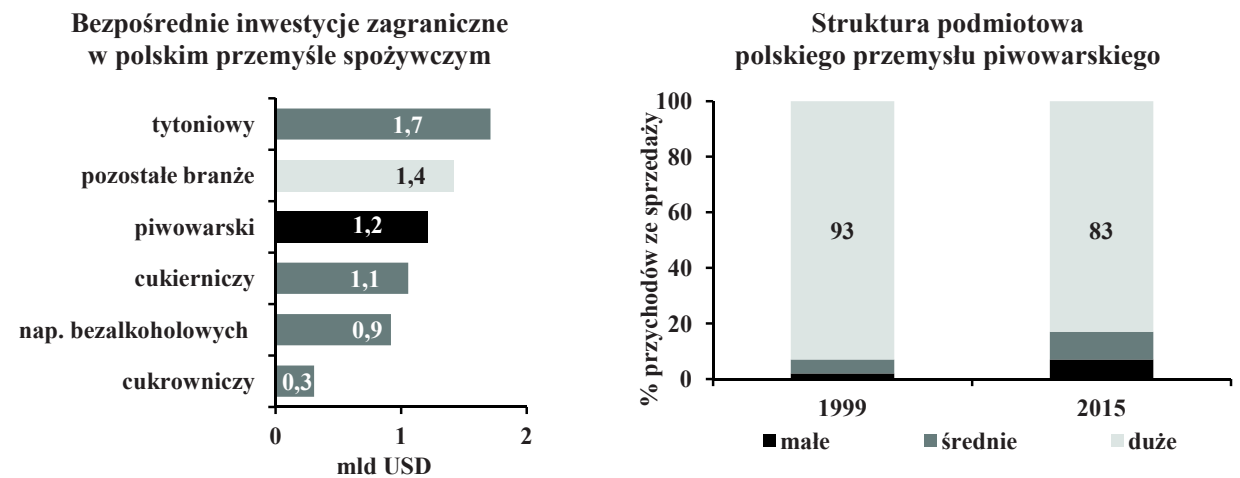

Rys. 2. Bezpośrednie inwestycje zagraniczne i struktura podmiotowa polskiego przemysłu piwowarskiego

Fig. 2. Foreign direct investments and the structure of Polish brewing sector

Źródło: opracowanie własne, niepublikowane dane GUS, (Chechelski 2008).

\section{Handel zagraniczny piwem}

W latach 1980-2016 odnotowano dynamiczny wzrost światowych obrotów handlowych piwem $^{4}$, pomimo intensyfikacji procesów globalizacyjnych i dużych bezpośrednich inwestycji zagranicznych transnarodowych koncernów browarniczych. Światowych eksport piwa wzrósł siedmiokrotnie do $158 \mathrm{mln} \mathrm{t}$ hl. W ujęciu wartościowym dynamika eksportu była jeszcze większa, gdyż wzrósł on jedenastokrotnie do ok. $13 \mathrm{mln}$ USD. Średnioroczna dynamika światowego handlu zagranicznego wyznaczona przy użyciu wykładniczej funkcji trendu wyniosła w ujęciu ilościowym 5,7\%, a wartościowo 7,6\% (rys. 3). Powodem większej dynamiki obrotów handlowych w ujęciu wartościowym były rosnące ceny transakcyjne.

Analiza porównawcza światowej produkcji i eksportu piwa wykazała, że systematycznie zwiększał się udział eksportu $\mathrm{w}$ produkcji. W ujęciu globalnym coraz większe ilości piwa są produkowane na sprzedaż na rynkach zewnętrznych. W $1980 \mathrm{r}$. światowy eksport stanowił 2,6\% światowej produkcji, a w 2016 r. udział wzrósł do 7,7\%.

\footnotetext{
${ }^{4}$ Światowe obroty handle zagranicznego piwem analizowano na podstawie eksportu przyjmując założenie, że w skali rynku światowego eksport jest równy importowi. Założenie to potwierdzają dane statystyczne. Dane statystyczne eksportu i importu wykorzystano jedynie w analizie struktury geograficznej obrotów handlowych.
} 

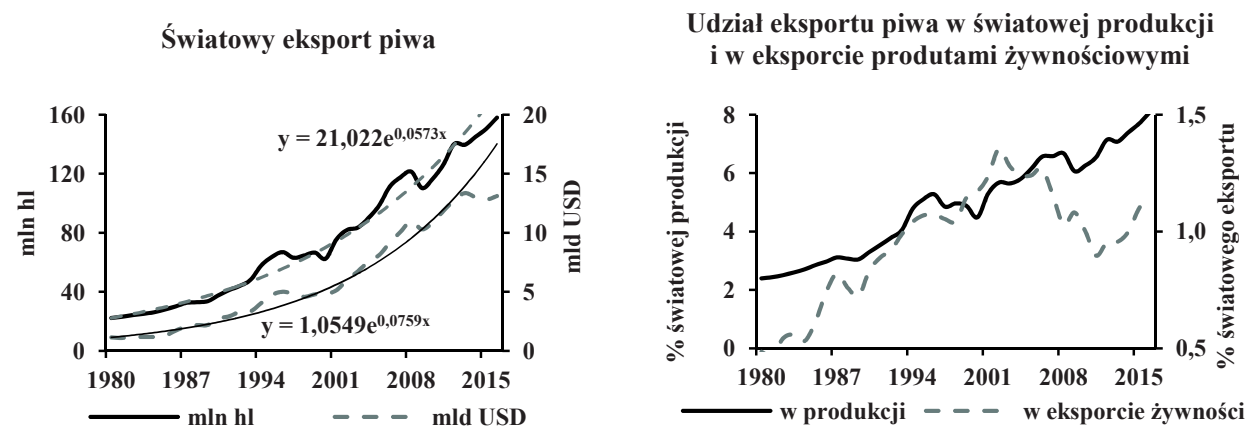

Rys. 3. Światowy handel zagraniczny piwem

Fig. 3. The world foreign trade in beer

Źródło: opracowanie własne, dane FAO (www.faostat.org), UN Comtrade (www.wits.worldbank.org).

W 2016 r. największymi światowymi eksporterami były: Meksyk (2,8 mld USD), Holandia (1,9 mld USD), Belgia (1,4 mld USD), Niemcy (1,3 mld USD), Wielka Brytania $(0,8$ mld USD) i USA $(0,6$ mld). Dużymi eksporterami są przed wszystkim państwa o ugruntowanej tradycji piwowarskiej. Największymi światowymi importerami były: USA (5,1 mld USD), Wielka Brytania (0,7 mld USD), Francja i Chiny (po 0,7 mld USD) oraz Włochy i Kanada (po 0,6 mld EUR). USA i Wielka Brytania są zarówno dużymi eksporterami, jak i importerami, co wskazuje, że światowy handel zagraniczny piwem charakteryzuje się dużą intensywnością wewnątrzgałęziową. Analogiczne tendencje występują na rynku UE, gdyż kraje członkowskie będące dużymi producentami (Hiszpania, Holandia, Francja) są także dużymi importerami. Powodem tego jest podobny popyt i preferencje konsumentów w krajach o zbliżonym poziomie rozwoju gospodarczego (tzw. hipoteza Lindera).

Analogiczne tendencje odnotowano w polskiej branży piwowarskiej, które w latach 1990-2016 charakteryzowała się dużym wzrostem wymiany handlowej. Średnioroczna dynamika wolumenu eksportu wyniosła $18,7 \%$, a importu 7,8\%, W 2016 r. eksport wyniósł $3,3 \mathrm{mln}$ hl i stanowił $8 \%$ produkcji. Import wzrósł do $0,7 \%$, ale jego udział w zaopatrzeniu rynku krajowego pozostał niewielki (2\%). Bilansowa konsumpcja piwa w Polsce (100 1/mieszkańca) zbliża się do granicy nasycenia i w związku z tym dalszy rozwój branży będzie w znacznym stopniu uzależniony od możliwości wzrostu eksportu (Rynek wyrobów alkoholowych ... 2017).

\section{Tendencje w uprawie jęczmienia i chmielu}

Przemysł piwowarski można zaliczyć do działów wtórnego przetwórstwa żywności, gdyż $\mathrm{w}$ procesie produkcyjnym są wykorzystywane surowce wytwarzane $\mathrm{w}$ innych branżach przemysłu spożywczego (Urban 2004). Głównym surowcem do produkcji piwa jest słód, który jest wytwarzany z jęczmienia browarnego, a w mniejszym zakresie $\mathrm{z}$ pszenicy. Przemysł słodowniczy jest branżą pierwotnego przetwórstw zbóż, ale występują również browary, które posiadają własne linie do produkcji słodu. Drugim ważnym surowcem wykorzystywanym $\mathrm{w}$ piwowarstwie jest chmiel. Szyszki chmielowe są przetwarzane $\mathrm{w}$ wyspecjalizowanych przedsiębiorstwach na ekstrakt chmielowy (alfa- 
kwasy). Ponadto w produkcji piwa surowcami są cukier oraz drożdże (Solomon, Katz 2003). Rosnąca światowa produkcja piwa generowała duży popyt na słód. Przyjmując, że średnia zawartość ekstraktu w piwie wynosi ok. 13\%, to zapotrzebowanie na słód wynosi ok. $24 \mathrm{mln}$ t. Do produkcji jednej tony słodu zużywa się jedną tonę jęczmienia browarnego. Według danych IGC światowe zbiory jęczmienia wynoszą 145-150 $\mathrm{ml} \mathrm{t}^{5}$. Do produkcji słodu zużywa się 16-17\% światowej produkcji jęczmienia. Potwierdzają to także dane Euromalt, że potencjał produkcyjny w światowego słodownictwa wynosi ok. $23 \mathrm{mln} \mathrm{t}$, w tym $42 \%$ mocy produkcyjnych przypada na zakłady w $\mathrm{UE}^{6}$.


Rys. 4. Tendencje w światowej produkcji chmielu

Fig. 4. Tendencies in the world hops production

Źródło: opracowanie własne, dane Barth-Haas Group.

Pomimo dynamicznie rosnącej produkcji piwa powierzchnia uprawy i zbiory chmielu w latach 1980-2016 wykazywały tendencję spadkową. Powierzchnia uprawy zmniejszała się średniorocznie o 6\% do 52 tys. ha. W latach 2000-2016 dynamika spadku areału uprawy uległa spowolnieniami z 59 tys. ha do 52 tys. ha. Średnioroczna dynamika spadku produkcji była nieznacznie mniejsza (ok.5\%), która w 2016 r. wyniosła 87,4 tys. t. Spadek produkcji szyszek chmielowych był rekompensowany rosnącą zawartością alfa-kwasów z $5,9 \%$ do $9,5 \%$. W rezultacie pomimo spadku zbirów chmielu nieznacznie wzrosła produkcja ekstraktu chmielowego (alfa-kwasów) do ok. 8 tys. t (rys. 4).

\section{Podsumowanie}

W analizowanym okresie światowy rynek piwa charakteryzował się wysoką dynamiką rozwoju. Potwierdzeniem tego jest rosnąca produkcja i obroty handlu zagranicznego. Analiza zmian produkcji w ujęciu regionalnym wykazała, że produkcja rozwijała się przede wszystkim na kontynencie azjatyckim i afrykańskim. Równocześnie w wielu krajach o ugruntowanej tradycji piwowarskiej uległa ona zmniejszeniu lub stabilizacji.

Stymulatorem rozwoju produkcji piwa w krajach rozwijających się gospodarczo były procesy globalizacyjne. Transnarodowe koncerny piwowarskie inwestowały w krajach charakteryzujących się dużym potencjałem wzrostu popytu. W konsekwencji tych przemian światowy rynek piwa należy do najbardziej zglobalizowanych rynków żywnościowych.

\footnotetext{
${ }^{5}$ International Grains Council, http://www.igc.int/en/markets/marketinfo-sd.aspx, (data odczytu 26.01.2018).

6 Euromalt, http://www.euromalt.be/list_infos/euromalt\%20statistics/1011306087/list1353668317.html, (data odczytu 26.01.2018).
} 
Duże koncerny browarnicze wytwarzają dominującą część światowej produkcji. W ostatnich latach ich udział w rynku uległ zmniejszeniu, co wskazuje na rozwój małych lokalnych browarów.

Wzrostowi światowej produkcji towarzyszy dynamiczny wzrost obrotów handlowych piwem. W rezultacie systematycznie zwiększał się udział eksportu w światowej produkcji. Wskazuje to, że w ujęciu globalnym coraz większe ilości piwa są produkowane $\mathrm{z}$ przeznaczaniem na eksport.

Polski rynek piwa w okresie transformacji polityczno-gospodarczej oraz członkostwa w UE przeszedł analogiczne tendencje rozwojowe jak rynek światowy. Duże bezpośrednie inwestycje globalnych koncernów skutkowały silną koncentracją struktury podmiotowej branży. Modernizacja zakładów i poprawa efektywności (dodatnie efekty sakli) skutkowały dynamicznym wzrostem produkcji i eksportu. W ostatnich latach także w Polsce jest obserwowany wzrost liczby małych browarów, które zwiększyły swój udział w produkcji i przychodach przemysłu browarniczego.

\section{Literatura}

Aczel, A.D. (2000). Statystyka w zarządzaniu (Statistics in Management),PWN, Warszawa.

Bierkompendium. Pobrano 03.01.2018 z: http://www.braufranken.de/html/bkgeschichte.html?B=2.

Chechelski, P. (2008). Wpływ procesów globalizacji na polski przemysł spożywczy (Impact of Globalisation on on Polish Food Industry). Studia i Monografie,145, IERiGŻ-PIB Warszawa.

Drożdż, J. (2016). Ocena sytuacji ekonomiczno-finansowej przemysłu spożywczego (Assesment of Financial Standing of Polish Food Industry). Studia i Monografie, nr 168, IERiGŻ-PIB, Warszawa.

Górecki, B.R. (2013). Ekonometria. Podstawy teorii i praktyki (Econometrics Basics for Theory and Practice). Key Text, Warszawa.

Köster, U. (2010). Grundzüge der landwirtschaftlichen Marktlehr., Verlag F. Vahlen, München.

Luderer, D., Nollau, V., Vetters, K. (2010). Mathematical Formulas for Economists. Springer, Heidelberg.

Łyszkiewicz, W. (2000). Industrial Organization. Organizacja rynku i konkurencja. Łuczak WSHiFM, Warszawa.

Pietrzak, M. (2014). Problem geograficznego zakresu rynków/sektorów w dobie globalizacji (The Problem of the Geographical Scope of the Markets/Sectors in the Era of Globalization and Regionalisation). Zagadnienia Ekonomiki Rolnej, 1, 3-21.

Pingali, P. (2006). Westernization of Asian diets and the transformation of food systems: Implications for research and policy. Food Policy, 32, 281-298.

PKO BP (2017). Rynek piwa w Polsce. Raporty branżowe (Beer Market in Poland. Branch Report). Pobrano z: http://www.pkobp.pl/centrum-analiz/analizy-sektorowe/raporty-branzowe/rynek-piwa-w-polsce/.

Porter, M. (2006). Strategia konkurencji. Metody analizy sektorów i konkurentów (Competitive Strategy. Techniques of Analyzing Industries and Competitors). MT Biznes, Warszawa.

Rynek wyrobów alkoholowych. Stan i perspektywy (2017). (Situation and Outlook on the Market of Alcohol), nr 5 IERiGŻ-PIB, ARR, MRiRW, Warszawa.

Solomon, W., Katz, H. (2003). Encyclopedia of Food and Culture, T. 1, Thomson-Gale, London.

Szymański, W. (2002). Globalizacja. Wyzwania i zagrożenia (Globalisation. Challenges and Threats). Difin.

Urban, R. (2004). Przemiany przemysłu spożywczego w latach 1988-2003 (Changes in Foof Industry over the period of 1988-2003). Studia i Monografie, nr 121, IERiGŻ-PIB, Warszawa.

Wiśniewski, P. (1993). Piwa historie niezwykłe (Extraordinary beer chronicles). Print Shops PREGO, Warszawa.

Do cytowania / For citation:

Szajner P. (2018). Ewolucja światowego rynku piwa. Problemy Rolnictwa Światowego, 18(4), 60-68; DOI: $10.22630 /$ PRS.2018.18.4.97

Szajner P. (2018). The Evolution of World Beer Market (in Polish). Problems of World Agriculture, 18(4), 60-68; DOI: 10.22630/PRS.2018.18.4.97 